\title{
Assessment of Paint Layers Quality by FTIR and DSC Techniques
}

\author{
EDUARD-MARIUS LUNGULESCU ${ }^{1}$, IOSIF LINGVAY', ADRIANA-MARIANA BORS²*, LASZLO FORTUNA ${ }^{3}$, \\ NICOLETA-OANA NICULA (BUTOI) ${ }^{1}$ \\ ${ }^{1}$ National Institute for Research and Development in Electrical Engineering INCDIE ICPE-CA, 313 Splaiul Unirii, 030138, Bucharest, \\ Romania \\ 2ICPE SA, 313 Splaiul Unirii, 030138, Bucharest, Romania \\ ${ }^{3}$ FORCORR Ltd, 3700 Kazincbarcika, Vajar utca 33. Hungary
}

\begin{abstract}
In order to identify the causes that led to microbiological degradation by biofouling increases a top coat painting layer applied to a railway bridge was analyzed by both FTIR and the DSC methods; the analysed painting material was that used to paint the bridge in 2013.The determinations were performed comparatively on samples of a similar painting material after 10 days of curing in a natural atmosphere at $25 \pm 5{ }^{\circ} \mathrm{C}$, after 60 days of storage under laboratory conditions $\left(22 \pm 5^{\circ} \mathrm{C}, \mathrm{RH} 60 \pm 10 \%\right.$, natural lighting), and on samples from the painting material of a certain railway bridge after approx. 4.5 years (exposed natural weathering of temperate climate with Mediterranean influences). From FTIR determinations, the amount of oxygen containing groups $(\mathrm{C}=\mathrm{O}, \mathrm{C}-\mathrm{O}, \mathrm{C}-\mathrm{O}-\mathrm{C},-\mathrm{HO})$ resulted from ageing under various conditions of the painting material.From DSC determinations, the resistance of the paint to the oxidative degradation decreases with the ageing time as resulted from oxidation onset temperatures and oxidation activation energies values which decreases with $4 \mathrm{~kJ} /$ mole (about $2.2 \%$ ) in only 60 days of storage in the laboratory and with $7 \mathrm{~kJ} /$ mole (about $3.9 \%$ ) following exposure to $100 \mathrm{w} / \mathrm{m}^{2}$ for only $15 \mathrm{~h}$ and $29 \mathrm{~kJ} / \mathrm{mole}$ (over $16 \%$ ) after exposure to 4.5 years of natural weathering.
\end{abstract}

Keywords: painting material, ageing, natural weathering, polyurethane, FTIR, DSC

In the sustainable development perspective ensuring a secure transport infrastructure is a priority issue. In this context, the development and use of efficient painting materials for the anticorrosion protection of metal structures related to transport infrastructure - such as bridges and viaducts - is a complex theoretical theme that has special practical (technical, economic and ecological) implications. Modern painting materials are composites based on polymeric material (usually polyurethanes, epoxy, etc.) with fillers of inorganic powders and various ingredients such as antioxidants, colour pigments etc. During exploitation, the painting layers are exposed to several stress factors specific to the exposure environment. Under the simultaneous and concerted action of stress factors, often with synergistic effects, paint layers aged and lose their anticorrosion protection capability.

In the paints case, stress factors usually act on the polymer matrix causing its degradation / ageing. In general, polymer degradation is a complex process in which a thermooxidation reaction [1-9] plays a determining role, which in the painting layers case is initiated by solar radiation in the IR spectrum and especially UV [10-12] and accelerated by climatic conditions specific to the operating environment [11, 13-15].

On the painting layers with degraded polymer the microorganisms, especially filamentous moulds (fig. 1) are fixed, which cause the polymeric protective layers biodegradation $[5,16-26]$.

The penetration of mycelial hyfes into the anticorrosion protection layers results in moisture retention and diffusivity increase of corrosive agents from the environment towards the metal support, so the polymeric layer loses its anticorrosion protection capability.

It is noted that in the paints case in which inorganic powders containing soluble salts (soluble salts of $\mathrm{K}, \mathrm{Na}$, Mg etc.) have been used as filler, the growth of filamentous moulds is accelerated, as reported in [27].

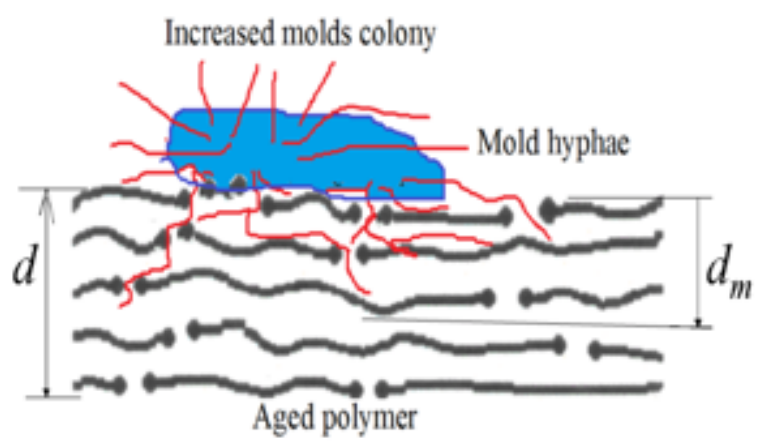

Fig. 1. Polymeric protective layers biodegradation: $\mathbf{d}$ - physical layer thickness; $\mathbf{d}_{\mathbf{m}}$ - the thickness of the biodegradation layer [16]

Both the painting materials manufacture and the metal painting operations have a negative impact on the environment (dispersion of various organic and inorganic noxes [28-30]), so it is desirable that the painting materials used are suitable for the application, and to provide highest stability and sustainability under the exploitation conditions, aiming at preserving and protecting the environment [31].

In the metal structures case related to transport infrastructures, particularly those operating in protected environments such as Natura 2000, the suitable painting material choice with high durability in operation is a complex issue.

Recently, a case of unexpectedly rapid biodegradation of the paint on a newly repainted railway bridge section has been reported [32].

Microbiological studies have shown the fact that filamentous moulds have a major contribution to the growth a complex fouling (filamentous moulds, moss, algae and lichens) [33] and to a significant decrease in the paint layer anticorrosion protection [16, 32].

In this context, the paper aim is to analyse the thermooxidative behaviour by means FTIR (DSC)

\footnotetext{
*email: adrianambors@gmail.com,Phone: +40773917319
} 


\begin{tabular}{|c|c|c|}
\hline \multicolumn{2}{|l|}{ Sample } & \multirow{2}{*}{ Remarks } \\
\hline Name & Code & \\
\hline Virgin paint & $S_{I}$ & Cured for 10 days at $25 \pm 5^{\circ} \mathrm{C}$ and $\mathrm{RH} 60 \pm 10 \%$ \\
\hline Paint stored in laboratory & $S_{2}$ & 60 days, at $20 \pm 3^{\circ} \mathrm{C}, \mathrm{RH} 60 \pm 10 \%$, day/night cycle \\
\hline Paint exposed to artificial UV light & $S_{3}$ & $\begin{array}{l}\text { Aged in a Xenotest } 440 \text { installation (Atlas Instruments, DE). } \\
\text { Irradiance: } 100 \mathrm{w} / \mathrm{m}^{2}(\lambda: 300-400 \mathrm{~nm}) \\
\text { Irradiation time: } 15 \mathrm{~h} ; \mathrm{RH}: 60 \% ; \mathrm{CHT}: 50^{\circ} \mathrm{C} ; \mathrm{BST}: 80^{\circ} \mathrm{C} \text {. }\end{array}$ \\
\hline $\begin{array}{l}\text { Paint sample taken from the bridge } \\
\text { of the biofouling area }\end{array}$ & St & Natural weathering - 4.5 years \\
\hline
\end{tabular}

Table 1

ANALYZED SAMPLES techniques and thermal analysis of the painting material which, in exploitation, proved to be easily biodegradable, as was described in [16, 27, 32, 33].

\section{Experimental part}

In order to assess the paint thermooxidative stability applied to a railway bridge, which proved to be easily biodegradable in exploitation, paint samples were taken from the painting layer from a certain bridge painted in 2013 [32].

Similar paint samples were exposed naturally to weathering and were analysed by FTIR and DSC technics, comparatively with paint samples of the same material after 10 days of curing, and after 60 days of storage under laboratory conditions and after controlled UV exposure. The samples analysed in this study and their ageing conditions are presented in table 1.

DSC measurements were performed using a Setaram 131 EVO instrument (Setaram, France). Dynamic measurements were carried-out at different heating rates of: $2.5,5,10,15^{\circ} \mathrm{C} / \mathrm{min}$, between $30-350^{\circ} \mathrm{C}$, under oxidant atmosphere (air, $50 \mathrm{~mL} / \mathrm{min}$ ). Samples of about $2-3 \mathrm{mg}$ were measured in aluminium pans of $30 \mu \mathrm{L}$ with a pierced lid. Specific SETARAM software has been used for data acquisition and processing. The oxidation onset temperatures (OOT) were calculated at different heating rates from the DSC curves.

FTIR measurements were carried-out using a J asco FTIR-4200 (Jasc, JP) coupled with an ATR (Attenuated Total Reflectance) module (JASCO PRO $470 \mathrm{H}$ ). The carbonyl and hidroxyl indexes were calculated using the following formulas:

$$
\begin{aligned}
& C I=\frac{A_{C=O}}{A_{C H 2}} \\
& H I=\frac{A_{O H}}{A_{C H 2}}
\end{aligned}
$$

where:

$A_{C=0}$ is the absorbance of carbonyl band, measured at the maximum peak in the range of $1650-1750 \mathrm{~cm}^{-1} ; A_{O H}$ is the absorbance of hydroxyl band, measured at the maximum peak in the range of $3300-3600 \mathrm{~cm}^{-1} ; A_{\mathrm{CH}_{2}}$ is the absorbance at $1458 \mathrm{~cm}^{-1}$ [34], used as internal standard.

\section{Results and discussions}

\section{FTIR spectroscopy}

FTIR analysis is a common technique used to assess the chemical changes in the polymer coatings as results of exposure to various external factors. In our case FTIR spectroscopy was used to characterize the ageing effects induced by the exposure of the paint in various environmental conditions (artificial UV, natural weathering, darkness) by observing the optical absorptions corresponding to the presence and groth of oxidative groups (carbonyl, carboxyl and hydroxyl) or the double bonds $(\mathrm{C}=\mathrm{C})$.

The absorption of natural or artificial UV radiations by polymeric materials involves the electrons excitation from the ground state to higher energy levels. These levels are unstable and induce some material structural modifications by various physico-chemical processes, known as photo degradation. This process can produce the scission (formation of low molecular weight compounds) and/or crosslinking (formation of higher molecular weight compounds) of the main polymer chain, unsaturation, photo-oxidation, photo-hydrolysis [35, 36].

Some polymeric structures, such as those containing aromatic rings, double bonds $(C=C, C=0)$, hydroxyl and carboxyl groups or some conjugate structures could absorb by themselves the UV radiations. The photooxidation is a chained process [37, 38], with a mechanism which implies the free radicals formation due to the photon absorption by the materials. These free radicals interact with oxygen molecules forming peroxy radicals. The peroxy radicals may remove a hydrogen atom from the polymer backbone, forming a hydroperoxide and another free radical, thus accelerating the degradation of the polymeric materials $[37,39,36]$.

In figure 2 are presented the ATR/FTIR spectra recorded on the investigated samples (table 1). The ATR/FTIR spectrum of unaged paint was used as standard. It presents the characteristic absorptions of polyurethane type coating materials (table 2).

The exposure of the polyurethane paint to various environmental conditions leads to some modifications in the ATR/FTIR spectrum, which are related to changes in

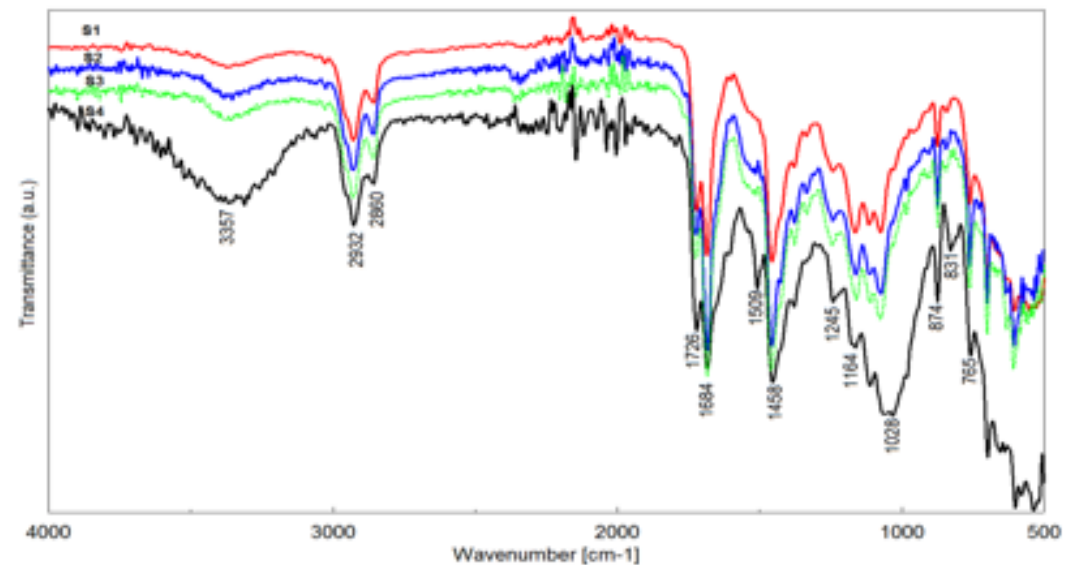

Fig. 2. ATR/FTIR spectra recorded on the investigated samples 


\begin{tabular}{|c|c|}
\hline $\begin{array}{c}\text { Wavenumber } \\
{\left[\mathrm{cm}^{-1}\right]}\end{array}$ & Assignment \\
\hline 3357 & -OH/NH stretching vibration \\
\hline 2932,2860 & Symmetric and antisymmetric stretch of $\mathrm{CH}_{2}$ \\
\hline 1726 & $\mathrm{C}=\mathrm{O}$ stretch from urethane \\
\hline 1684 & $\mathrm{H}$ bond $\mathrm{C}=\mathrm{O}$ stretch/tertiary urethane $\mathrm{C}=\mathrm{O} / \mathrm{C}=\mathrm{O}$ bonded \\
\hline 1509 & -NH deformation and antisymmetric stretch of C-N \\
\hline 1458,1378 & Scissoring and bending of $-\mathrm{CH}_{2}-$ group \\
\hline 1426 & $-\mathrm{OH}$ deformation \\
\hline 1330 & NCO deformation/CH \\
\hline 1245 & (O=) C-O-C stretch/Urethane C-O stretch \\
\hline $1200-1000$ & C-O-C stretching vibrations \\
\hline 1164 & C-N-C asymmetric stretch \\
\hline 874 & C-N-C symmetric stretch \\
\hline 831 & C-O (Hydroperoxide) [44] \\
\hline 765 & C-N stretch \\
\hline
\end{tabular}

Table 2

CHARACTERISTIC ABSORPTION BANDS OF S1 [34, 43, $52,44,55]$ the chemical structure of the material. The most prominent modifications (fig. 2 and fig. 3) are observed for the paint exposed in natural weathering (S4), mainlyin the region of $-\mathrm{NH} /-\mathrm{OH}$ stretching vibrations $\left(3100-3500 \mathrm{~cm}^{-1}\right)$ and in the spectral ranges of $\mathrm{C}=0\left(1600-1750 \mathrm{~cm}^{-1}\right)$ [45] and C-O-C $\left(1000-1200 \mathrm{~cm}^{-1}\right)[34,43,45]$. These structural modifications of the $\mathrm{C}=0$ and $\mathrm{C}-\mathrm{O}-\mathrm{C}$ groups are mainly caused by photooxidative processes [52].

The broadening and intensity increase of the peak with maximum at $3357 \mathrm{~cm}^{-1}$ is due to the $\mathrm{O}-\mathrm{H}$ stretching mode of a hydroperoxide ( $\mathrm{R}-\mathrm{O}-\mathrm{O}-\mathrm{H})$, hydroxide (R-O-H), species produced in the photodegradation process of the polyurethane paint [38]. The increase in intensity of the band at $1726 \mathrm{~cm}^{-1}$ (fig. 3, table 2) is related to the increase of the concentration of carbonyl groups due to â-scission of the alkoxy radical $[40,41]$, while the decrease of the intensity of the peak of $1684 \mathrm{~cm}^{-1}$ indicates chain scissions of the urethane linkages [34].

The scission of the polyurethane chain produces more oxygen containing groups as revealed by the increasing in the intensity and the broadening of the bands corresponding to C-O stretching vibrations ( $1000-1200 \mathrm{~cm}^{-1}$, with a maximum at about $1028 \mathrm{~cm}^{-1}$ ) [42], and by the broadening of the band between $1680-1750 \mathrm{~cm}^{-1}$, due to the formation of differenttypes of carbonyl groups [43], respectively. Also, the increase in intensity of the band at $831 \mathrm{~cm}^{-1}$ is given the FTIR spectrum of S4 samples. This is also attributed to formation of single bond, carbon-oxygen (e.g. hydroperoxide) [44].

The exposure to artificial UV radiation $\left(\boldsymbol{S}_{\mathbf{3}}\right)$ does not modify significantly the paint chemical structure, as revealed by ATR/FTIR analysis, the spectrum being similar to that of $\boldsymbol{S}_{2}$ sample (fig. 3). This can be attributed both to the short ageing time (about $15 \mathrm{~h}$ ) or to the fact that, firstly, the UV energy is used to finish the paint curing process, and only after that the material degradation occurs.
However, a slight increase for carbonyl and hydroxyl index values (table 3) for $\boldsymbol{S}_{3}$ as compared to $\boldsymbol{S}_{2}$ is noticed.

In table 3 are presented the hydroxyl $(\mathrm{HI})$ and carbonyl (CI) indexes obtained from the ATR/FTIR spectra [39, 45, 46]. These parameters reflect the influence of the various stress factors on the material, being a tool to evaluate its photodegradation state.

Table 3

CARBONYL AND HYDROXYL INDEXES

\begin{tabular}{|c|c|c|c|}
\hline Sample & CI $_{1726}$ & $\mathbf{C I}_{1654}$ & $\mathbf{H I}_{3357}$ \\
\hline S1 & 0.86 & 1.81 & 0.13 \\
\hline S2 & 1.06 & 1.62 & 0.15 \\
\hline S3 & 1.07 & 1.58 & 0.15 \\
\hline S4 & 1.57 & 1.55 & 0.74 \\
\hline
\end{tabular}

As expected, the paint exposed in natural conditions (UV light, variable temperatures and humidity) present higher values for carbonyl and hydroxyl indexes. The paint stored for 60 days in laboratory conditions with partial access at the light seems to be also a little bit more degraded than the unaged paint.

\section{Differential scanning calorimetry}

The DSC curve of virgin paintS 1 recorded under oxidant atmosphere at $10^{\circ} \mathrm{C} / \mathrm{min}$ is shown in figure 4 . The Onset Oxidation Temperature (OOT), also known in literature as Oxidation Induction Temperature (OIT*, [47]), is a widely used parameter in thermal analysis of polymers to monitor their degradation oxidation state under various stress factors (UV light, gamma irradiation, temperatures) [48, 39]. The OOT values recorded on the analyzed samples at different heating rates are presented in table 4 . As it can be observed, as the heating rate is increased, the OOT are shifted to higher values due to heat transfer lag [49]. Also, the 00T values decrease with the ageing time from 223 ${ }^{\circ} \mathrm{C}$ ( heating rate $\beta=10{ }^{\circ} \mathrm{C} / \mathrm{min}$ ) for S1 to $209^{\circ} \mathrm{C}$ for S3.

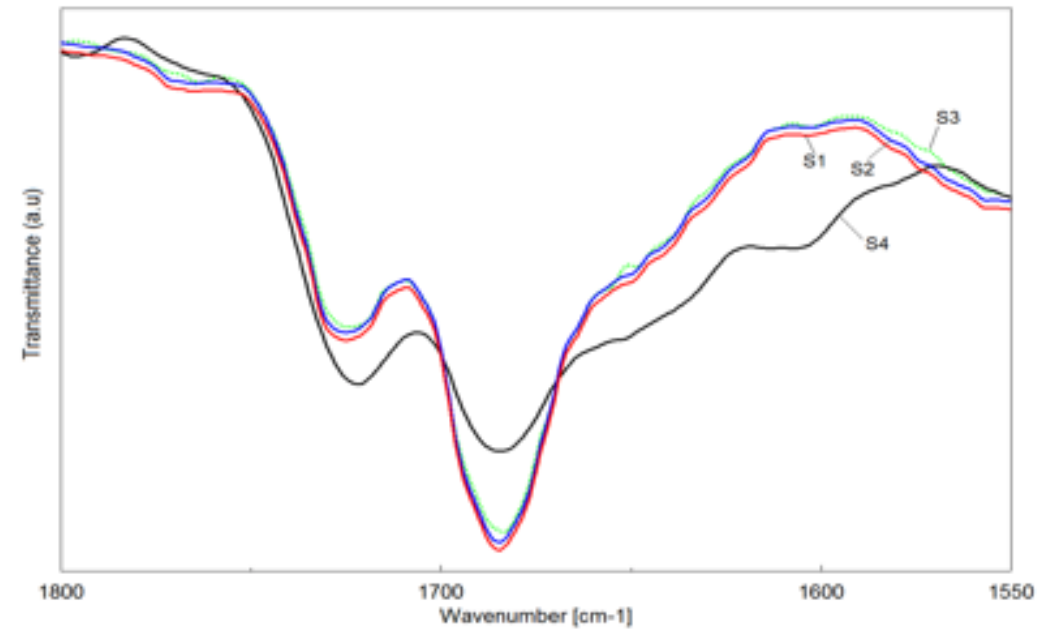

Fig. 3. ATR/FTIR spectra recorded on the carbonyl groups region of the investigated samples 


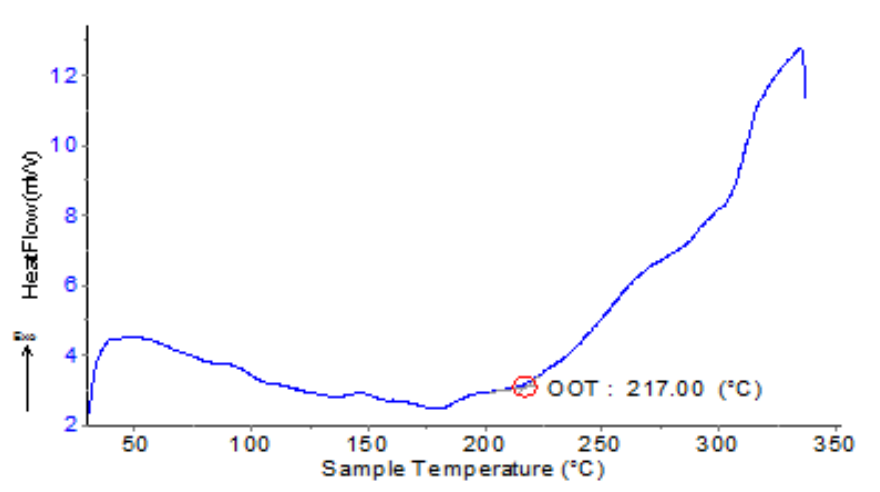

Fig. 4. DSC curve $\left(10^{\circ} \mathrm{C} / \mathrm{min}\right)$

These results are in good agreement with the ATR/FTIR, revealing that with the increase of the ageing time of the paint the carbonyl and hydroxyl indexes increase, simultaneously with an O0T decrease.

The activation energy is a parameter used to investigate different transformations into the polymeric materials such crystallization, degradation/oxidation, decomposition, etc. [50]. The environmental factors effect on physicochemical behavior of polymeric system can be also evaluated in terms of activation energies. In oxidation terms of a polymeric material, the activation energy is the minimum amount of energy necessary to start the oxidation process.
In our case, the oxidation activation energies were calculated using the Kissinger method [51], from the slope of $\ln \left(00 T^{2} / \beta\right)$ vs. $1 / 00 T$ ( $\beta$ is $x x$ the heating rate?; the slope is in fact as $E a / R$, were $E a$ is activation energy, expressed in Kelvin ( $\mathrm{K}$ ) degrees, and $\mathrm{R}$ - the gas constant; $\mathrm{R}=8,314 \mathrm{~J} \mathrm{\textrm {K } ^ { - 1 }}$ mole $\mathrm{e}^{-1} ; 00 \mathrm{~T}$ is expressed also in $\mathrm{K}$ degrees). An example for obtaining the oxidation activation energy for the unaged sample $\left(\boldsymbol{S}_{1}\right)$ is given in table 4 . The plots of the $\ln \left(00 T^{2} / \beta\right)$ vs. $1 / 00 T^{2}$ are shown in figure 5 and in table 5 are given the activation energies for all analyzed samples.

As can be observed (table 5) the activation energy for the oxidation process decreases as the ageing time increases.

The decrease by $4 \mathrm{~kJ} / \mathrm{mole}$ (about $2.2 \%$ ) in only 60 days of laboratory storage and by $7 \mathrm{~kJ} / \mathrm{mole}$ (about $3.9 \%$ ) following exposure to $100 \mathrm{w} / \mathrm{m}^{2}$ for only 15 hours indicates a low thermal stability of the material, which is confirmed by the substantial decrease of $29 \mathrm{~kJ} /$ mole (over $16 \%$ ) after the exposure of 4.5 years to natural weathering.

The low thermal stability of the polymer, also confirmed by the SEM image (with major bumps and cracks) of the top coat exposed at 4.5 years in natural weathering presented in [27], correlated with the content in chlorine, phosphorus, potassium, sodium and magnesium of the painting material [27] can explain the weak resistance to microorganisms action of the investigated paint layer.

\begin{tabular}{|c|c|c|c|c|}
\hline Heating rate & \multicolumn{4}{|c|}{ OOT $\left[{ }^{\circ} \mathrm{C}\right]$} \\
\cline { 2 - 5 }$\left[{ }^{\circ} \mathbf{C} /\right.$ min $]$ & S1 & S2 & S3 & S4 \\
\hline 2.5 & 208 & 207 & 207 & 197 \\
\hline 5 & 217 & 216 & 214 & 204 \\
\hline 10 & 223 & 221 & 220 & 209 \\
\hline 15 & 227 & 227 & 226 & 218 \\
\hline
\end{tabular}

Table 4

HEATING RATES AND AGEING CONDITIONS INFLUENCE ON OOT VALUES

\begin{tabular}{|c|c|c|c|c|c|c|c|}
\hline $\begin{array}{c}\boldsymbol{\beta}^{*} \\
{\left[\mathrm{~K} \text { min }^{-1}\right]}\end{array}$ & $\begin{array}{l}\text { OOT } \\
{\left[{ }^{\circ} \mathrm{C}\right]}\end{array}$ & $\begin{array}{c}\text { OOT } \\
{[\mathrm{K}]}\end{array}$ & $\begin{array}{c}\text { 1/OOT } \\
{\left[\mathrm{K}^{-1}\right]}\end{array}$ & $\begin{array}{l}\mathrm{OOT}^{2} / \beta \\
{[\mathrm{K} \cdot \mathrm{min}]}\end{array}$ & $\ln \left(\mathrm{OOT}^{2} / \beta\right)$ & $\begin{array}{c}E_{\alpha} / R \\
{[\mathrm{~K}]}\end{array}$ & $\begin{array}{c}E_{\alpha} \\
{\left[\mathrm{kJ} \mathrm{mole} \mathrm{e}^{-1}\right]}\end{array}$ \\
\hline 2.5 & 208 & 481.15 & 0.002078 & 92602.1 & 11.44 & \multirow{4}{*}{21673} & \multirow{4}{*}{180} \\
\hline 5 & 217 & 490.15 & 0.002040 & 48049.4 & 10.78 & & \\
\hline 10 & 223 & 496.15 & 0.002015 & 24636.3 & 10.11 & & \\
\hline 15 & 227 & 500.15 & 0.001999 & 16683.3 & 9.72 & & \\
\hline
\end{tabular}

${ }^{8}$ conventionally, the heating rate $\beta$ is expressed as $\mathrm{K} \mathrm{min}^{-1}$

\begin{tabular}{|c|c|c|}
\hline Sample & $E_{\alpha} / R[\mathrm{~K}]$ & $E_{\boldsymbol{\alpha}}[\mathrm{kJ}$ mole \\
\hline$S_{I}$ & 21673 & 180 \\
\hline$S_{2}$ & 21159 & 176 \\
\hline$S_{3}$ & 21012 & 173 \\
\hline$S_{4}$ & 18946 & 151 \\
\hline
\end{tabular}

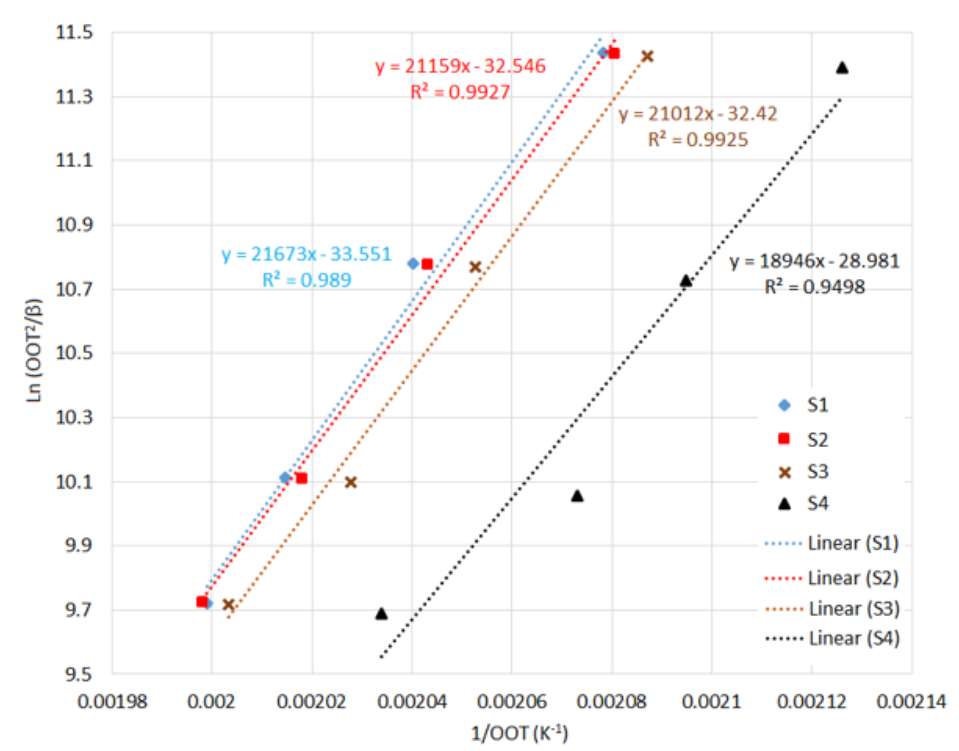

Table 5

ACTIVATION ENERGY OBTAINED FOR $\mathbf{S}_{1}$
Table 6

ACTIVATION ENERGIES E OBTAINED FOR ALL ANALYZED SAMPLES USING DSC OOT VALUES AND KISSINGER [51] METHOD

Fig. 5. Plots of $\ln \left(\mathrm{OOT}^{2} / \mathrm{a}\right)$ vs. 1/OOT (Kissinger [51] method) 


\section{Conclusions}

The ATR/FTIR and DSC techniques were used to assess the degradation state of some polyurethane coating at different ageing times and conditions.

The exposure of polyurethane coating samples to environmental conditions for different period of times leads to the increase of the amount of oxygen containing groups $(\mathrm{C}=\mathrm{O}, \mathrm{C}-\mathrm{O}, \mathrm{C}-\mathrm{O}-\mathrm{C},-\mathrm{HO})$, to the appearance of some UV induced scission processes on the polymer chains, as compared to the unaged sample.

The resistance of the paint to the oxidative degradation decreases with the ageing time as resulted from OOT and oxidation activation energies values.

The decrease by $4 \mathrm{~kJ} / \mathrm{mole}$ (about $2.2 \%$ ) for only 60 days of laboratory storage and $7 \mathrm{~kJ} / \mathrm{mole}$ (approximately $3.9 \%$ ) following exposure to $100 \mathrm{w} / \mathrm{m}^{2}$ for only $15 \mathrm{~h}$ and 29 $\mathrm{kJ} /$ mole (over $16 \%$ ) after 4.5 years exposure to natural weathering, are values indicating reduced thermooxidative stability of the investigated painting material.

Acknowledgment: This work was financially supported by the UEFISCDI of Romania, under the scientific Programme PN 1824010235N/2018 and INR DUBNA Collaboration, Project: 04-4-1122-2015/2020. Also thank for funding by the contract type $D$, no.11384/18.06.2018 ("ECO-NANO-ECO); contract 30PFE/2018 (between National R\&D Institute for Electrical Engineering ICPE-CA and Romanian Ministry of Research and Innovation - MCI)

\section{References}

1.VISAN, S., CIOBOTARU, V., IONESCU, F., BUDRUGEAC, P., GHIGA, C., Mat. Plast., 42, no. 3, 2005, p. 177.

2.LINGVAY, I., STANCU, C., BUDRUGEAC, P., CUCOS, A., LINGVAY, C. 2011 7th International Symposium on Advanced Topics in Electrical Engineering, ATEE 2011, 5952210.

3.AMMALA, A., BATEMAN, S., DEAN, K., PETINAKIS, E., SANGWAN, P., WONG, S., YUAN, Q., YU, L., COLIN, P., LEONG, K.H., Progress in Polymer Science, vol. 36, no. 8, 2011, p. 1015.

4. LINGVAY, J., BUDRUGEAC, P., Korroz. Figy., vol. 48, no. 3, 2008, p. 45.

5.LINGVAY, J., GROZA, C., LINGVAY, C., CSUZI, I., Korróz. Figy., vol. 49, no. 3, 2009, p. 31.

6.VOICU, R., Mat. Plast., 52, no. 3, 2016, p. 465.

7.RUS, T., BORS, A.-M., CARAMITU, A.-R., LINGVAY, I., VAIREANU, D.I., Mat. Plast., 55, no. 2, 2018, p. 167.

8. RUS, T., CARAMITU, A.- R., UNGUREANU, L.-C., MARINESCU, V., BORS, A.-M., VAIREANU, D.-I., Mat. Plast., 55, no. 1, 2018. p. 28.

9. LUNGULESCU, E.-M., LINGVAY, I., UNGUREANU, L.- C., RUS, T., BORS, A.-M., Mat. Plast, 55, no. 2, 2018. p. 201.

10. RUS, T., CARAMITU, A., MITREA, S., LINGVAY, I., IEEE Xplore, 2016, p. 60.

11. JIANWEN, H., XIAOGANG, L., IIN, G., QUANLIN, Z., Materials and Design, vol. 30, 2009, p. 1442.

12. RUS, T., LINGVAY, I., CARAMITU, A.-R., BORS, A.-M., VAIREANU, D.-I., Mat. Plast., 44, no. 4, 2017, p. 720.

13. JIANWEN, H., XIAOGANG, L., JIN, G., QUANLIN, Z., Progress in Organic Coatings, vol. 65, 2009, p. 504.

14. OPRINA, G., RUS, T., LINGVAY, D., CARAMITU, A., MITREA, S., Electrotehnica, Electronica, Automatica (EEA), vol. 65, no. 1, 2017, p. 81.

15. YANG, X.F., TALLMAN, D.E., BIERWAGEN, G.P., CROLL, S.G., ROHLIK, S., Polymer Degradation and Stability, vol. 77, 2002, p. 103. 16. LINGVAY, I., FORTUNA, L., VARGA, E., BORS, A.-M., NICULA (BUTOI), N.O., LINGVAY, D., Durability and Anticorrosive Protection Capability of Paint Layers - Biological Factors Influence, Electrotehnica, Electronica,Automatica (EEA), 2018,66, no. 4, p. 52-58

17. ASHWINI, R., ANCHANA DEVI, C., International J ournal of Biology Research, vol. 3, no. 1, 2018, p. 180.

18. VOINA, A., Nla, P., LUCHIAN, A.-M., BUTOI N., BOR', A.-M., LINGVAY, I., Electrotehnica, Electronica, Automatica (EEA), vol. 65, no. 2, 2017, p. 60.

19. LEJA, K., LEWANDOWICZ, G., Polish J. of Environ. Stud., vol. 19, no. 2, 2010, p. 255.

MATERIALE PLASTICE $\bullet 5 \bullet$ No. $1 \bullet 2019$
20. BORS, A.M., BUTOI, N., CARAMITU, A.R., MARINESCU, V., LINGVAY, I., Mat. Plast., 44, no. 3, 2017 , p. 447.

21. CARAMITU, A., BUTOI, N., RUS, T., LUCHIAN, A.-M., MITREA, S., Mat. Plast., 44, no. 2, 2017, p. 331.

22. GNANAVEL, G., VALLI, V.P.M.J., THIRUMARIMURUGAN, M., International Journal of Pharmaceutical and Chemical Sciences, vol. 1, no. 3, 2012, p. 670.

23. RUS, T., RADU, E., LINGVAY, I., LINGVAY, M., CIOBOTEA-BARBU, 0.-C., CAMPUREANU, C., BENGA, F.-M., LAZAR, G.-C., VAIREANU, D.I., U.P.B. Sci. Bull., Series B, vol. 79, no. 4, 2017, p. 167.

24. LOREDO-TREVINO, A., GUTIERREZ-SANCHEZ, G., RODRIGUEZHERRERA, R., AGUILAR, C. N., J. Polym. Environ, vol. 20, 2012 , p. 258. 25. BUTOI, N., LUCHIAN, A-M., CARAMITU, A., MITREA, S., RUS, T., Electrotehnica, Electronica, Automatica (EEA), vol. 65, no. 1, 2017, p. 72.

26. RAVIKUMAR, H.R., RAO, S.S., KARIGAR, C.S., Indian Journal of Science and Technology, vol. 5, no. 1, 2012, p. 1977.

27. LINGVAY, I., BORS, A.-M., MARINESCU, V., MITREA, S., VARGA, E., Evaluarea calitãii straturilor de vopsea. 3 - Analiza prin tehnicile SEMEDAX si XRF a straturilor de vopsea aplicate pe un pod de cale feratã, Mat. Plast., 55, no. 4, 2018, p. 531-535

28. MEGHEA, I., BORS, A.G., MUNTEANU, G.-V., MUNTEANU, C., BORS, A.-M, International Multidisciplinary Scientific GeoConference Surveying Geology and Mining Ecology Management, SGEM, 1, 2013, p. 1113.

29. NEAMTU, S., BORS, A.-M., STEFAN, S., Rev. Chim. (Bucharest), 58, no. 9, 2007, p. 938.

30. BORS, A.-M., MEGHEA, A., NEAMTU, S., LESNIC, M., Rev. Chim. (Bucharest), 58, no. 8, 2007, p. 776.

31. STERE, E.A., POPA, I., Electrotehnica, Electronica, Automatica (EEA), vol. 66, no. 3, 2018, p. 125.

32.VARGA, E., FORTUNA, L., LINGVAY, D., BORS, A.-M., NICULA, (BUTOI) N.O., LINGVAY, I., Mat. Plast., 55, no. 3, 2018, p. 320 33.NICULA, (BUTOI) N.O., VARGA, E., BORS, A.-M., LINGVAY, I., Mat., Plast., 55, no. 4, 2018, p. 626

34.DAS, S., PANDEY, P., MOHANTY, S., NAYAK, S.K., J . Inorg. Organomet. Polym., vol. 27, 2017, p. 641.

35.LUNGULESCU, E.M., ZAHARESCU, T., Chapter: Stabilization of polymers against photodegradation. In Photochemical Behavior of Multicomponent Polymeric-based Materials, Rosu, D., Visakh, P.M., (Ed.), Advanced structured materials, Springer, vol. 26, 2016, p. 165. ISSN 1869-8433

36.PERRIN, F.X., MERLATTI, C., ARAGON, E., MARGAILLAN, A., Progress in Organic Coatings, vol. 64, no. 4, 2009, p. 466.

37.KOSYANCHUK, L.F., KOZAK, N.V., BABKINA, T.V., ROSHCHIN, O.M., BEZRODNYI, V.I., ANTONENKO, O.I., BROVKO, 0.0., Opt. Mater., vol. 85, 2018, p. 408.

38.ALLEN, N.S., EDGE, M., Elsevier Applied Science, 1992, ISBN 185166-773-3

39.ILIE, S., SETNESCU, R., LUNGULESCU, E.M., MARINESCU, V., ILIE, D., SETNESCU, T., MARES, G., Polym. Test., vol. 30, 2011, p. 173.

40.GRASSIE, N., SCOTT, G., Polymer Degradation and Stabilization. London: Cambridge University Press (1985)

41.YOUSIF, E., HADDAD, R., Springer Plus, vol. 2, 2013, p. 398

42.LIU, Y., LIU, X., LIU, S., TAN, H., J. Wuhan Univ. Technol. Mater. Sci. Ed. vol. 29, no. 6, 2014, p. 1270.

43.DEFEYT, C., LANGENBACHER J., RIVENC, R., Herit. Sci., vol. 5, 2017 , p. 1.

44.OPREA, S., OPREA, V., Mat. Plast., vol. 47, no. 1, 2010, p. 44. 45.LUDWICK, A., AGLAN, H., ABDALLA, M.O., CALHOUN, M., J. Appl. Polym. Sci., vol. 110, 2008, p. 712.

46.CORRALES, T., CATALINA, F., PEINADO, C, ALLEN, N.S., FONTAN, E., J. Photoch. Photobio A, vol. 147, no. 3, 2002, p. 213.

47.SCHMID, M., RITTER, A., AFFOLTER, S., J. Therm. Anal. Calorim., vol. 83, 2006, p. 367.

48.VOLPONI J.E., MEI, L.H.I., ROSA, D.S., J. Polym. Environ., vol. 12, 2004, p. 11.

49.STRELLA, S., ERHARDT, P.F., J. Appl. Polym. Sci., vol. 13, no. 7, p. 1373.

50.WELLEN, R.M.R, CANEDO, E.L., Polym. Test., vol. 40, 2014, p. 33. 51.KISSINGER, H.E., Analyt. Chem., vol. 29, no. 11, 1957, p. 1702.

52.XU, L., LI, C., NG, K.Y.S., J. Phys. Chem. A. vol. 104, 2000, p. 3952.

Manuscript received: 13.12 .2018

http://www.revmaterialeplastice.ro 